\title{
Visualisasi 3D Objek Menggunakan Teknik Fotogrametri Jarak Dekat
}

\author{
Sarkawi Jaya Harahap dan Hepi Hapsari Handayani \\ Jurusan Teknik Geomatika, Fakultas Teknik Sipil dan Perencanaan, Institut Teknologi Sepuluh Nopember (ITS) \\ Jl. Arief Rahman Hakim, Surabaya 60111 Indonesia \\ e-mail: hapsari@geodesy.its.ac.id
}

\begin{abstract}
Abstrak- Fotogrametri Jarak Dekat (Close Range Photogrammetry) adalah teknik fotogrametri dengan menggunakan prinsip kesegarisan atau kolinearitas, namun dalam pengambilan data dilakukan pada jarak dekat yakni $100 \mathrm{~mm}$ sampai dengan $300 \mathrm{~m}$. Seiring perkembangan Perkembangan teknologi era digital semakin memudahkan manusia dalam menyelesaikan masalah. Perhitungan CRP dapat digunakan dengan metode image matching, Image matching ini memiliki kegunaan antara lain : melakukan proses orientasi relatif, pembentukan 3D model, pembentukan DEM (Digital Elevation Model), serta pembuatan ortofoto. Dalam penelitian ini melakukan visualisasi 3D model objek dengan memanfaatkan teknologi komputer dalam melakukan pengukuran 3D Teknik Fotogrametri jarak dekat pada objek kontainer (beraturan). Bentuk objek tersebut memiliki ukuran kecil sehingga pengukuran GCP (Ground Control Point menggunakan alat pita ukur. Visualisasi 3D Objek dapat dibentuk dari point cloud dan data DEM (Digital Elevation Model).

Kalibrasi dikalukan dengan dua cara yaitu kalibrasi secara otomatis (image maching) pada objek grid dan kalibrasi analitik (manual) pada objek kontainer. Hasil kedua kalibrasi dapat dilihat bahwa nilai panjang fokus memiliki perbedaan yang relatif kecil sebesar 0,142 mm. Nilai koordinat pusat kamera memiliki perbedaan selisih sebesar $0,503 \mathrm{~mm}$ untuk sumbu $x$ dan $0,117 \mathrm{~mm}$ untuk sumbu y. Selisih nilai $K_{1}, K_{2}$, dan $K_{3}$ pada kedua kalibrasi sebesar 0,0000169; 0,000 dan 0,000. Sedangkan nilai koefisien $P_{1}$ dan $P_{1}$ memiliki selisih sebesar 0,$000498 ; 0,000$. Perbedaan nilai kalibrasi kamera diatas dapat dipengaruhi oleh kondisi objek kalibrasi. Dan ketelitian koordinat 3D objek kalibrasi otomatis lebih akurat terhadap koordinat ICP pita ukur, yaitu $80 \%$ kordinat $X, Y$, dan $Z$ dapat diterima, sedangkan hasil koordinat $3 D$ model kalibrasi analitik yaitu $60 \%$ titik koordinat $Y$ dapat diterima dan $80 \%$ titik koordinat $X$ dan $Z$ dapat diterima.
\end{abstract}

Kata Kunci: Close Range Photogrammetry, Kalibrasi Kamera,, 3D Model

\section{PENDAHULUAN}

$\mathrm{F}$ OTOGRAMETRI Jarak Dekat merupakan suatu cabang penting ilmu fotogrametri dengan kamera berada di permukaan bumi yang menpunyai jarak antara kamera dengan objek sampai dengan 300 meter. Kamera Foto ini mudah dicapai sehingga dapat dilakukan pengukuran langsung untuk memperoleh posisi pemotretan [1]. Penggunaan metode alternatif yang relatif murah untuk melakukan pemodelan suatu bangunan, yakni dengan teknologi Close Range Photogrametry (CRP) atau Fotogrametri Rentang Dekat, dengan memanfaatkan kamera Digital Single Lens
Reflex (DSLR) .Dalam teknik CRP, kualitas proses penentuan koordinat dapat ditingkatkan dengan cara melakukan pembidikan ke objek secara konvergen dari kamera agar diperoleh ukuran lebih. Teknik ini mempunyai kelebihan terutama jika objek yang akan diukur sulit untuk dijangkau dan atau memiliki dimensi yang kecil [2]. Dengan aplikasi lain yaitu dalam penentuan volume suatu bidang [3].

Prinsip Dasar dalam penyelesaian permasalahan Fotogrametri Jarak Dekat adalah dengan menerapkan prinsip persamaan kondisi kolinearitas. Kolinearitas merupakan kondisi dimana stasiun pemotretan foto, titik objek, dan gambar foto, semua terletak pada satu garis lurus. Persamaan kolinearitas yang digunakan adalah [4] :

$$
\begin{gathered}
x_{a}-x_{0}=-f \frac{m_{11}\left(X_{A}-X_{L}\right)+m_{12}\left(Z_{A}-Z_{L}\right)+m_{13}\left(Y_{A}-Y_{L}\right)}{m_{a 1}\left(X_{A}-X_{L}\right)+m_{a 2}\left(Z_{A}-Z_{L}\right)+m_{a 3}\left(Y_{A}-Y_{L}\right)} \\
y_{a}-y_{0}=-f \frac{m_{11}\left(X_{A}-X_{L}\right)+m_{12}\left(Z_{A}-Z_{L}\right)+m_{1 a}\left(Y_{A}-Y_{L}\right)}{m_{a 1}\left(X_{A}-X_{L}\right)+m_{a 2}\left(Z_{A}-Z_{L}\right)+m_{a a}\left(Y_{A}-Y_{L}\right)}
\end{gathered}
$$

Dengan $x_{\alpha}$ dan $y_{\alpha}$ merupakan koordinat titik A di foto, $x_{0}$ dan $y_{0}$ merupakan koordinat titik utama, koordinat $X_{A} Y_{A}$ dan $Z_{A}$ merupakan koordinat titik A pada objek, $X_{L} Y_{L}$ dan $Z_{L}$ merupakan koordinat pusat pemotretan, $f$ merupakan panjang fokus kamera, dan $m$ merupakan elemen matriks rotasi.

Image maching atau biasa disebut automatic streo matching dimulai pada tahun 50-an yang dilakukan oleh Hobrough dengan mencocokkan 2 foto berdasarkan derajat keabuan atau grey levels [5]. Image Maching suatu proses mencari atau mengidentifikasi pasangan suatu titik yang muncul pada dua foto atau lebih secara otomatis. Pada instrumen analog/analitik image matching dilakukan oleh operator secara manual menggunakan persepsi 3D mata kiri dan kanan.

Penelitian ini dilakukan untuk mengetahui bagaimana cara melakukan pembntukan 3D model objek dengan menggunakan metode CRP. Objek yang digunakan memiliki bentuk beraturan, yaitu memiliki bentuk kotak yang bertujuan untuk mengurangi kesalahan dalam pengukuran. Pengukuran dengan pita ukur dilakukan keperluan CRP dikarenakan objek pengukuran memiliki ukuran relatif kecil. Kalibrasi kamera dilakukan menggunakan perhitungan Bundle Adjusment Laboratory Calibration pada dua objek, yaitu objek grid untuk kalibrasi otomatis (image matching) dan objek kotak sebagai objek penelitian untuk kalibrasi analitik (manual). Hasil 
visualisai 3D objek dari hasil kedua kalibrasi tersebut akan dibandingakn ketelitian koordinat beerdasarkan uji statistika dengan koordinat pengukuran pita ukur yang dianggap benar.

\section{METODOLOGI PENELITIAN}

\section{A. Lokasi Penelitian}

Lokasi penelitian Tugas Akhir ini dengan objek kotak kontainer berlokasi di halaman Workshop Mobil Listrik ITS, kampus ITS Sukolilo Surabaya.

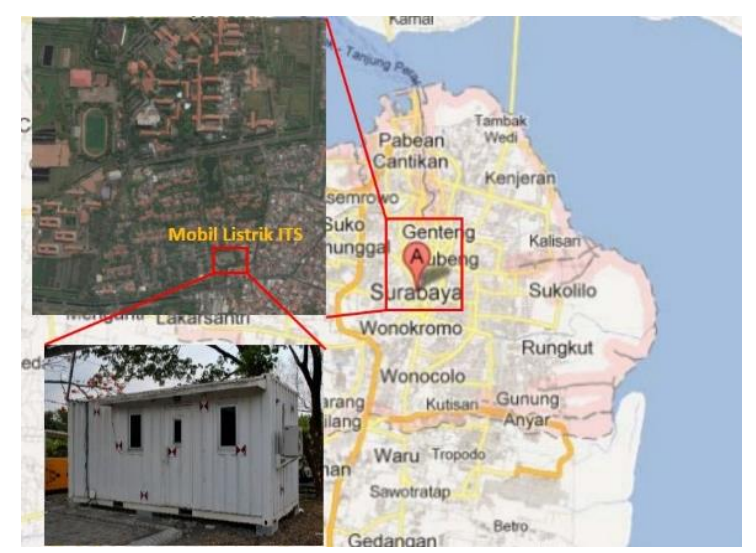

Gambar 1. Lokasi dan objek penelitian

\section{B. Data dan Perangkat Lunak}

Data

Data yang digunakan dalam penelitian ini atara lain :

a. Bidang kalibrasi kamera 2D berupa grid untuk kalibrasi otomatis dan foto kalibrasi objek kontainer untuk kalibrasi Analitik (manual).

b. Data spesifikasi kamera digital non-metrik Nikon D3000.

c. Data pengukuran Grund Control Point (GCP) kontainer menggunakan pita ukur.

d. Foto-foto objek kontainer untuk pembentukan 3d model.

\section{Peralatan}

Peralatan yang digunakan dalam penelitian ini terbagi dalam kelompok hardware (perangkat keras) dan software (perangakt lunak) yaitu :

1. Perangkat keras

a. Kamera digital non-metrik SLR Nikon D3000 10 megapiksel, CCD Sensor APS-C (23,6 x 15,8), resolusi piksel $3872 \times 2592$, digunakan sebagai alat untuk pengabilan foto kalibrasi dan pembuatan 3D model

b. Pita ukur Komelon Unigrip Flx Kmc 1800 berukuran panjang 30 meter, dengan skala bacaan terkecil milimeter, bahan pita Fiber Glass.

c. Laptop sebagai alat pengolahan data

2. Perangkat Lunak

a. Perangkat pengolah data fotogrametri

b. MATLAB untuk pengolahan data kalibrasi Analitik.

\section{Tahapan Pengolahan Data}

Tahapan pengolahan data yang dilakukan pada penelitiian ini terbagi menjadi 2 yaitu, tahapan pengolahan kalibrasi kamera dan pengolahan data CRP.

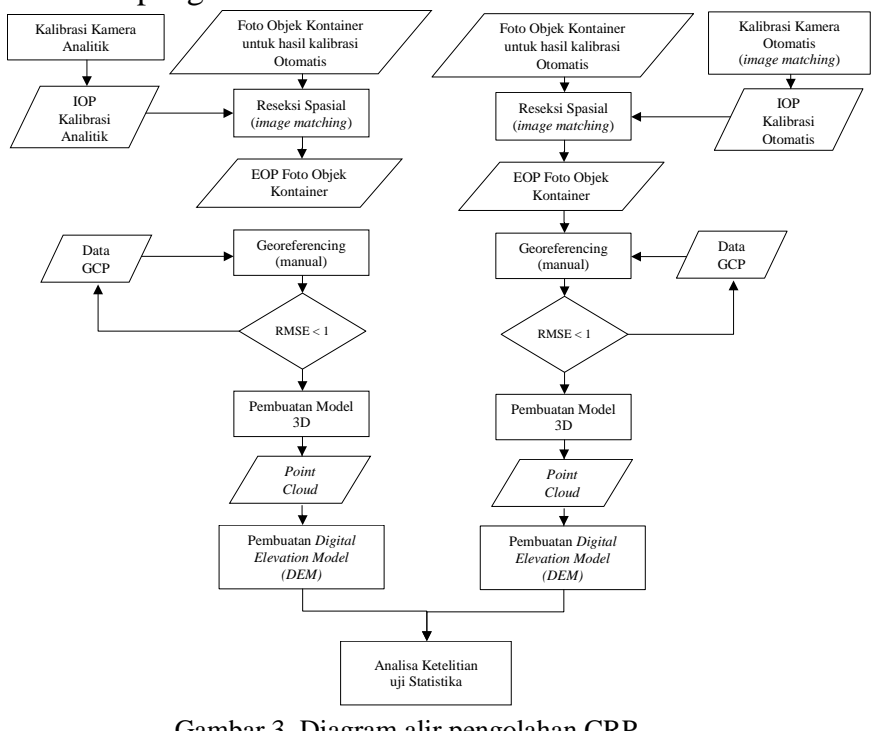

Penjelasan diagram alir diatas adalah sebagai berikut:

1. Kalibrasi kamera Otomatis

Kalibrasi kamera otomatis pada objek grid 2D secara otomatis dilakukan menggunakan software menggunakan bidang grid 2D memiliki 100 titik dengan 4 titik kontrol. Pemotretan kalibrasi dilakukan dengan empat sisi dengan masing-masing sisi terbagi menjadi 3 foto, yaitu foto dengan posisi landskape dan 2 foto dengan posisi potrait masingmasing rotasi 90 ke-kanan dan 90 ke-kiri. Jumlah pengambilan foto serta intensitas pencahayaan sangat mempengaruhi kualitas kalibrasi kamera. Kemudian dilakukan pengolahan kalibrasi secara otomatis (image maching dengan metode self calibration. Dalam hal ini kalibrasi yang baik harus memiliki RMS $\leq 1$ piksel. Selain itu titik-titik kalibrasi harus terorientasi satu sama lain minimal $80 \%$.

2. Kalibrasi kamera analitik (manual)

Kalibrasi dengan objek kontanier bertujuan untuk mendapatkan geometris IOP lebih baik daripada grid 2D. Adapun kegiatan dalam melakukan kalibrasi bidang objek kontainer adalah sebagai berikut:

a. Penempatan titik kontrol yang tersebar secara merata pada objek kontainer sebelum melakukan pemotretan. Jumlah desain titik kotrol berjumlah 16 titik GCP.

b. Melakukan pengukuran GCP dengan alat ukur pita ukur masing-masing GCP dengan sistem koordinat 3D (X,Y dan Z).

c. Melakukan pemotretan bidang kalibrasi.

d. Melakukan ektraksi koordinat GCP dalam piksel (2D).

e. Melakukan transformasi koordinat piksel GCP ke koordinat foto dalam $\mathrm{mm}$ dengan memasukkan data spesifikasi kamera yaitu ukuran sensor dan ukuran piksel foto. 
f. Melakukan proses reseksi spasial untuk mendapatkan nilai parameter orientasi luar (EOP) yaitu Xl. Yl, Zl, Omega, phi dan kappa.

g. Melakukan proses Bundle Adjustment Laboratory Calibration untuk mendapatkan nilai orientasi dalam (IOP). Proses Bundle Adjustmen Self Calibration dilakukan secara simultan sampai mencapai nilai konstan pada setiap parameter IOP kamera, sehingga nilai RMSE $<1 \mathrm{~mm}$.

3. Pengolahan data CRP dilakukan dengan kegiatan berikut ini:

a. Penentuan titik GCP yang tersebar pada objek kontainer.

b. Titik GCP tersebut di ukur dengan pita ukur untuk mendapatkaan data jarak. Sehingga mendapatkan koordinat 3D (X, Y dan Z). Titik GCP ini digunakan untuk georeferencing pada foto.

c. Pengolahan data CRP dilakukan dengan dua software yang berbeda, sehingga pengolahan foto juga dilakukan dengan foto yang berbeda.

d. Reseksi spasial atau orientasi reltif dilakukan secara otomatis dengan metode image matching pada software. Reseksi spasial ini bertujuan untuk mendapatkan koordinat stasiun pemotretan dan orientasi kamera (Xl, Yl, Zl, Omega, phi, Kappa).

e. Georeferencing dilakukan dengan memasukkan koordinat GCP hasil pengukuran untuk mendapatkan koordinat nyata pada foto. Georeferencing ini dilakukan secara manal dengan melakukan marking pada foto yang bertampalan. Hasil Georeferencing ini harus memiliki RMSE < 1 piksel.

f. Langkah selanjutnya adalah pembuatan 3D Model dengan mengasilkan permukaan objek dalam bentuk point cloud. Point cloud ini kemudian dibentuk menjadi data Digital Elevation Model (DEM).

\section{HASIL DAN ANALISA}

\section{A. Hasil dan Analisa Kalibrasi Kamera Objek Otomatis}

Pada pengolahan kalibrasi kamera otomatis dapat diketahui nilai parameter internal seperti panjang fokus terkalibrasi adalah $24,216 \mathrm{~mm}$. Hal ini terdapat selisih perubahan panjang fokus awal sebesar 0,216 mm. Principal point (koordinat pusat kamera) pada sensor kamera memiliki nilai Xp dan Yp masing-masing $11,968 \mathrm{~mm}$ dan $7,884 \mathrm{~mm}$. Nilai koordinat kamera $0,0 \mathrm{~mm}$ berada di posisi pojok kanan atas, seperti yang diilustrasikan pada gambar 4.8 dibawah. Nilai K1, K2, dan K3 masing-masing bernilai $0,0001 \mathrm{~mm},-0,00000003$ dan 0,000 $\mathrm{mm}$. Nilai K3 tidak dapat dihitung, karena pada perangkat lunak nilai K3 digunakan ketika memiliki wide angle lenses.

Untuk mendapatkan akurasi yang baik pada kalibrasi harus memiliki nilai RMS dibawah 1 piksel. Tetapi hasil kalibrasi menunjukkan terdapat nilai lebih besar dari satu piksel, yaitu 1,32 piksel pada titik 5 photo 12 . Hal ini dikarenakan pada saat pemotretan terdapat kesalahan terutama kurangnya pencahyaan sehingga mengakibatkan perbedaan gradasi warna atara satu foto dengan foto yang lain. Sedangkan nilai RMS secara umum memiliki nilai 0,272 piksel dimana memiliki nilai lebih kecil dari 1 piksel. Jumlah area foto yang tertutupi oleh titik adalah 79\%, hal ini merupakan kurang $1 \%$ untuk mencapai $80 \%$.

Tabel 1.

Hasil Parameter Internal Kamera

\begin{tabular}{ccc}
\hline \hline $\begin{array}{c}\text { Parameter } \\
\text { Internal }\end{array}$ & $\begin{array}{c}\text { Nilai } \\
(\mathrm{mm})\end{array}$ & Standar Deviasi \\
\hline Panjang Fokus & 24,216 & 0,003 \\
Xp & 11,968 & 0,003 \\
Yp & 7,884 & 0,004 \\
K1 & 0,0001 & 0,000002 \\
K2 & 0,0000018 & 0,00000001 \\
K3 & 0 & 0 \\
P1 & 0,00002 & 0,000002 \\
P2 & $-0,000008$ & 0,000002 \\
& & \\
\hline \hline
\end{tabular}

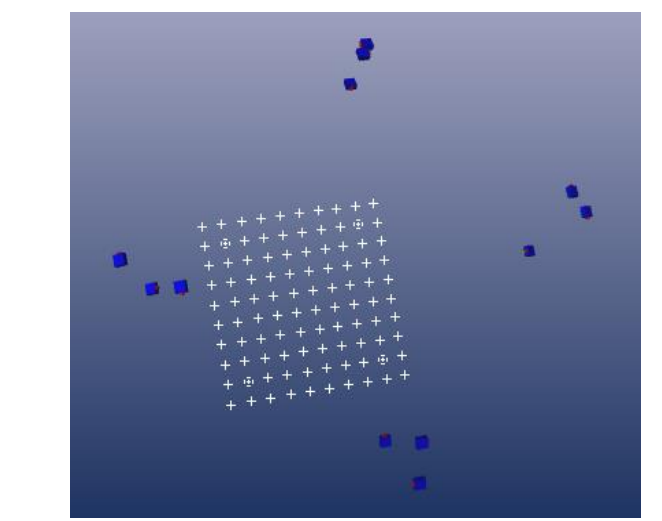

Gambar 4. Tampilan posisi kamera dan titik GCP kalibrasi

Tabel 2.

Kualitas Kalibrasi Kamera

\begin{tabular}{ccc}
\hline \hline Kualitas & Parameter & Nilai \\
\hline Foto & Jumlah Foto & 12 \\
kalibrasi & Jumlah terorientasi & 12 \\
\hline \multirow{2}{*}{ Kamera } & Jumlah foto yang digunakan & 12 \\
& Area foto ter-cover & $79 \%$ \\
\hline & RMS Keseluruhan & 0,272 piksel \\
Titik & Maksimum & 1,317 piksel \\
Residual & Minimum & 0,202 piksel \\
& RMS Maksimum & 0,107 piksel \\
Kerapatan & RMS Minimum & 0,107 piksel \\
titik & Maksimum & $0,00083 \mathrm{~m}$ \\
Presisi & Minimum & $0,00016 \mathrm{~m}$ \\
\hline Titik & RMS panjang vector keseluruhan & $0,00009 \mathrm{~m}$ \\
& Panjang vektor maksimum & $0,0001 \mathrm{~m}$ \\
\hline \hline
\end{tabular}

\section{B. Hasil dan Analisa Kalibrasi Analitik (Manual)}

Foto kalibrasi objek kontainer menggunakan panjang fokus yang sama dengan kalibrasi laboratorium grid 2D yaitu 24 $\mathrm{mm}$. Hal ini telah disesuaikan dengan kondisi lapangan pada saat pemotretan. Titik GCP berjumlah 16 titik terebar secara teratur dengan jarak antar titik untuk $\mathrm{x}$ dan y adalah $100 \mathrm{~cm}$ dan $60 \mathrm{~cm}$ diukur menggunakan pita ukur. 


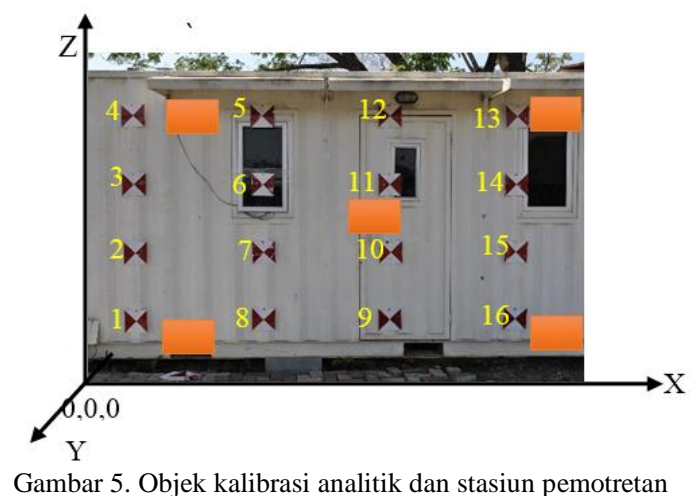

Proses Bundle Adjustment Self Calibration dilakukan secara simultan sampai mendapatkan nilai yang stabil hingga 12 kali pengulangan (iterasi). Adapun hasil kalibrasi kamera dapat dilihat dari 5 foto dapat dilihat pada tabel 3 dibawah ini.

Tabel 3.

Hasil Parameter Internal Kamera Objek Kontainer

\begin{tabular}{cc}
\hline \hline IOP & $\begin{array}{c}\text { Value } \\
(\mathrm{mm})\end{array}$ \\
\hline Focal Length & 24,358 \\
Xp & $-0,535$ \\
Yp & $-0,237$ \\
K1 & 0,0003 \\
K2 & $-0,000002$ \\
K3 & 0,000 \\
P1 & 0,0005 \\
P2 & $-0,0001$ \\
\hline \hline
\end{tabular}

Pada pengolahan kalibrasi objek kontainer dapat diketahui kualitasnya seperti stabilitas perubahan setiap iterasi Bundle Adjustment Self Calibration. Selisih iterasi dapat dilihat kokonstanan atau nilai perubahan setiap iterasi. Pararameter Xp mencapai nilai konstan pada iterasi 10, Yp mencapai nilai konstan pada iterasi ke 6, panjang fokus (f ) dan K1 mencapai nilai konstan pada iterasi 9, K2 mencapai nilai konstan pada iterasi ke 10, K3 pada ietrasi 8, P1 pada iterasi 10, dan P2 pada iterasi 11. Masing-masing parameter memiliki menunjukkan bahwa kekontanan nilai perubahan berbeda-beda satu sama lain. Nilai parameter orientasi dalam yang digunakan pada iterasi ke 12. Kamera SLR Nikon D3000 merupakan jenis kamera format kecil karena memiliki panjang fokus 18-55 mm. Kamera ini memiliki distorsi lensa yang cukup besar karena mencapai nilai stabil pada iterasi ke 8 .

Kesalahan radial dapat diketahui dari perhitungan koefisien distorsi radial (K1, K2 dan $\mathrm{K} 3$ ) dengan jarak radial dengan mengikuti deret aritmatika dimana nilai jarak radial mengalami kenaikan order perkalian setiap koefisien yang berbeda. Jika nilai kesalahan radial $<1$ maka maka lensa kamera mengalami distorsi cembung. Sedangkan nilai kesalahan radial $>1$, maka lensa kamera mengalami distorsi cekung. Pada tabal dibawah diketahui nilai kesalahan radial pada foto tengah kurang dari 1, sehingga dapat dikatakan lensa kamera SLR D3000 mengalami distorsi cembung.
Tabel 4.

Kesalahan Radial Pada Foto Tengah (satuan mm)

\begin{tabular}{ccc}
\hline \hline Tititk & $\mathrm{X}$ & $\mathrm{Y}$ \\
\hline 1 & $-0,136$ & $-0,072$ \\
2 & $-0,121$ & $-0,019$ \\
3 & $-0,125$ & 0,026 \\
4 & $-0,145$ & 0,084 \\
5 & $-0,022$ & 0,041 \\
6 & $-0,009$ & 0,006 \\
7 & $-0,008$ & $-0,004$ \\
8 & $-0,020$ & $-0,032$ \\
9 & 0,023 & $-0,034$ \\
10 & 0,011 & $-0,004$ \\
11 & 0,012 & 0,007 \\
12 & 0,027 & 0,043 \\
13 & 0,154 & 0,086 \\
14 & 0,133 & 0,027 \\
15 & 0,130 & $-0,019$ \\
16 & 0,144 & $-0,072$ \\
\hline \hline
\end{tabular}

\section{Hasil dan Analisa Pembentukan 3D Model Objek}

Pengolahan foto menjai 3D Model dilakukan beberapa tahapan seperti, reseksi spasial secara otomatis dan secara manual, georferencing, pembentukan point cloud untuk mendapatkan bentuk permukaan objek, dab pembentukan DEM.

Reseksi spasial secara otomatis dilakukan untuk mendapatkan posisi stasiun kamera dan orientasi sudut terhadap posisi objek, sedangkan reseksi spasial secara manual digunakan sebagai titik GCP lapangan.

Foto yang digunakan untuk membentuk model 3D berjumlah 56 buah foto dengan pengambilan jarak antara stasiun rata-rata 1 meter dan jarak antara kamera terhadap objek rata-rata 4 meter. Posisi pengambilan foto kamera tegak lurus terhadap objek. Bagian atas objek tidak dilakukan pengambilan foto karena dianggap memiliki permukaan yang rata.

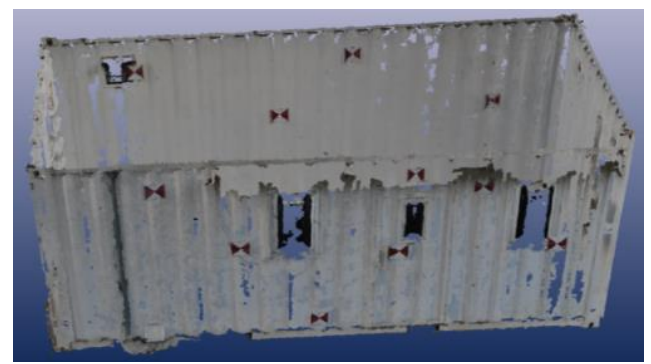

Gambar 6. Hasil Dense Surface Modelling untuk pembentukan point cloud (hasil kalibrasi otomatis)

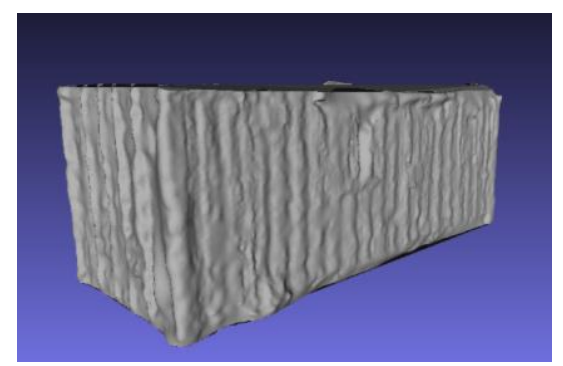

Gambar 7. Hasil 3D model setelah melakukan proses triangulation 
Pengolahan foto 3D CRP pada objek dilakukan secara otomatis menggunakan perangkat pengolahan CRP. Proses tersebut terdiri dari proses reseksi spasial yang dilakukan secara otomatis antar foto yang sesui, pembentukan point cloud, serta pembentukan DEM. Jumlah foto yang digunakan berjumlah 48 foto. Teknik pengambilan foto sesuai dengan frame (area) pengambilan foto pada saat melakukan kalibrasi dengan jarak antara stasiun rata-rata 1 meter.
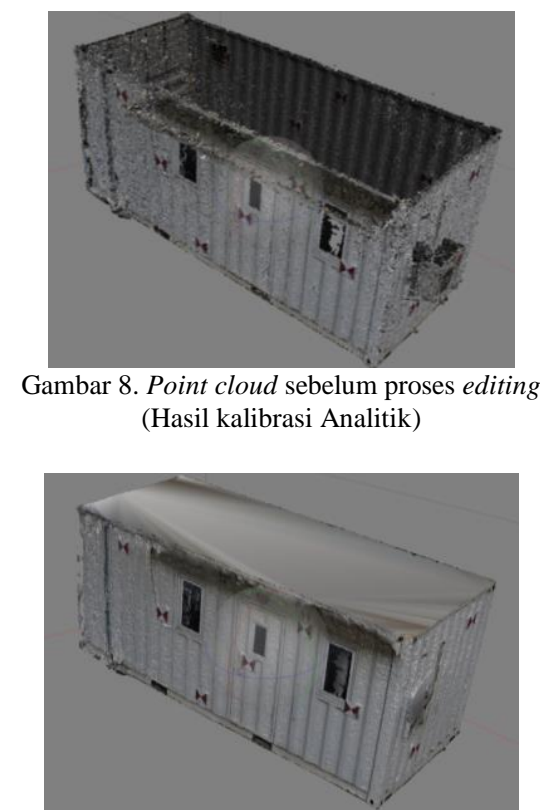

Gambar 9. Hasil 3D model setelah melakukan proses editing

Analisa bentuk 3D Model hasil kalibrasi otomatis pada pengolahan foto masih terdapat kekurangan. Pada gambar 4.16 diatas proses pembetukan point cloud belum sempurna. Dilihat dari bentuk DSM yang tidak tertutupi. Adapun faktor penyebabnya seperti kualitas foto, metode pengambilan foto serta terdapat objek lain yang dapat menghalangi pembentukan 3D Model. Kualaitas foto dapat dipengaruhi dengan pencahayaan yang kurang, hal ini mengakibatkan pembentukan DEM yang kurang baik. Analisa Planimetris dapat dilihat dari data orientasi relatif secara otomatis dan manual. Secara otomatis berjumlah 11.706 titik, sedangkan jumlah titik oreintasi relatif secara manual berjumalah 12 titik.

Hasil Pada pengolahan foto dengan 12 titik GCP pada model kalibrasi analitik memiliki RMSE 0,359 piksel atau 0,002 mm. Nilai RMSE tersebut $<1$ piksel. Ukuran 1 piksel pada foto sama dengan 0,006 mm pada koordinat foto. Analisa bentuk 3D Model hasil kalibrasi objek kontainer dapat dilihat pada gambar 4.20. Gambar tersebut terlihat sempurna dan memililiki tekstur yang jelas pada permukaan objek. Pada bagian atas dan bawah dapat tertutup secara otomatis sehingga pembuatan DEM dapat dilakukan dengan sempurna. Bentuk permukaan yang bergelombang juga dapat dibedakan dari bentuk 3D
Model ini. Hal ini metode image macthing pada pengolahan foto ini memiliki kualitas yang bagus.

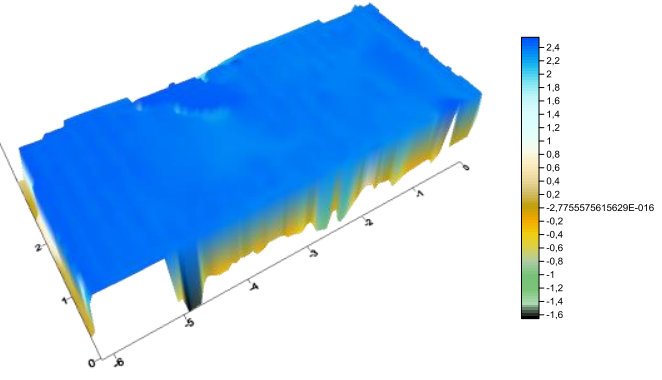

Gambar 10. Tampilan DEM hasil kalibrasi Otomatis

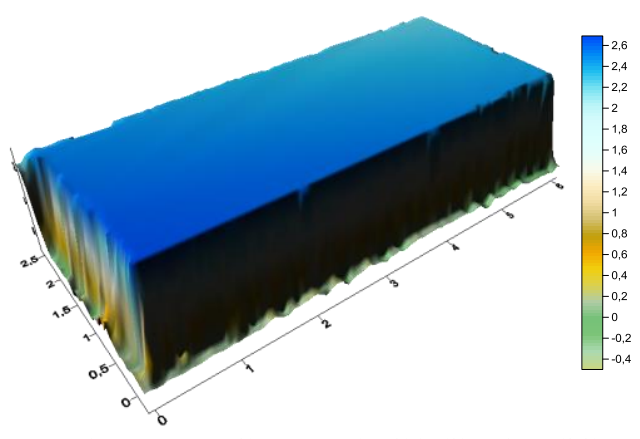

Gambar 11. Tampilan DEM hasil kalibrasi analitik

\section{Pengukuran dengan Pita Ukur}

Pengukuran jarak horiontal dengan pita ukur merupakan penerapan panjang yang diketahui pada pita berpembagian skala langsung pada sebuah garis beberapa kali. Metode pengukuran jarak dengan pita ukur dengan mengurangkan bacaan skala pita ukur dibelakang dengan bacaan skala pita ukur didepan. Untuk mengurangi kesalahaan dalam pengukuran ini maka dilakukan pegukuran berulang kali. Jika panjang objek yang diukur lebih kecil dari panjang pita ukur yang digunakan, maka langsung dapat ditentukan jarak ketia titik tersebut. Dalam hal ini menggunakan pita ukur 30 meter, sedangkan jarak objek kontainer maksimal sebesar 6,040 meter sehingga dapat ditentukan jarak antara titik tanpa dilakukan pengukuran bertahap. Pengukuran GCP dalam penelitian ini untuk medapatkan data GCP kalibrasi analitik dan GCP georeferencing 3D Objek dan koordinat ICP.

\section{E. Uji Statistik}

Analisa uji statistika pada pemodelan 3D dilakukan dengan membandingkan koordinat hasil 3D Model dengan koordinat ICP (Independent Check Point). Kordinat ICP merupakan kordinat GCP yang tidak dimasukkan pada saat melakukan georeferencing. Perbandingan hasil koordinat ICP 3D Model dengan koordniat ICP hasil pengukuran pita ukur dilakukan menggunakan uji stastistik $t$-student. Titik ICP hasil pengukuran pita ukur berjumlah 5 titik.Hipotesa nol diterima atau ditolah maka dibutuhkan konsultasi terhadap tabel distribusi $t$-student dimana derajat kepercayaan yang digunakan adalah $90 \%$ dengan metode berupa two-tailed test dimana $\mathrm{H}_{0}$ ditolak jika $\mathrm{T}>\mathrm{t}_{\alpha / 2, \mathrm{n}}$ atau $\mathrm{T}<-\mathrm{t}_{\alpha / 2, \mathrm{n}}$ maka $\alpha=10 \%$, 
maka nilai $t$ pada tabel $t$-student bernilai 2,92 dengan derajat bebas $n$ adalah 2 .

Tabel 4.

Hasil Uji t-Student Koordinat X (meter)

\begin{tabular}{lcccc}
\hline \hline Nama & $\begin{array}{l}\text { Min } \\
\text { Interval }\end{array}$ & $\begin{array}{l}\text { Max. } \\
\text { Interv } \\
\text { al }\end{array}$ & $\begin{array}{l}\text { 3D Model } \\
\text { kalibrasi } \\
\text { Analitik }\end{array}$ & $\begin{array}{c}\text { 3D Model kalibrasi } \\
\text { Otomatis }\end{array}$ \\
\hline ICP1 & 2.039 & 2.101 & 2.076 & 2.076 \\
ICP2 & 6.009 & 6.071 & 6.061 & 6.031 \\
ICP3 & 2.604 & 2.666 & 2.62 & 2.646 \\
ICP4 & 0.019 & 0.081 & 0.047 & 0.071 \\
ICP5 & -0.031 & 0.031 & 0.0912 & 0.039 \\
\hline \hline
\end{tabular}

Tabel 5 .

Hasil Uji t-Student Koordinat Y (meter)

\begin{tabular}{ccccc}
\hline \hline Nama & $\begin{array}{c}\text { Min } \\
\text { Interval }\end{array}$ & $\begin{array}{c}\text { Max. } \\
\text { Interval }\end{array}$ & $\begin{array}{c}\text { 3D Model } \\
\text { kalibrasi } \\
\text { Analitik }\end{array}$ & $\begin{array}{c}\text { 3D Model } \\
\text { kalibrasi } \\
\text { Otomatis }\end{array}$ \\
\hline ICP1 & -0.084 & 0.084 & -0.024 & -0.028 \\
ICP2 & 1.751 & 1.919 & 1.933 & 1.897 \\
ICP3 & 2.346 & 2.514 & 2.447 & 2.425 \\
ICP4 & 2.098 & 2.266 & 2.044 & 2.074 \\
ICP5 & 2.346 & 2.514 & 2.493 & 2.416 \\
\hline \hline
\end{tabular}

Tabel 6.

Hasil Uji t-Student Koordinat Z (meter)

\begin{tabular}{ccccc}
\multicolumn{5}{c}{ Hasil Uji t-Student Koordinat Z (meter) } \\
\hline \hline Nama & $\begin{array}{l}\text { Min } \\
\text { Interval }\end{array}$ & $\begin{array}{l}\text { Max. } \\
\text { Interv } \\
\text { al }\end{array}$ & $\begin{array}{l}\text { 3D Model } \\
\text { kalibrasi } \\
\text { Kontainer }\end{array}$ & $\begin{array}{c}\text { 3D Model } \\
\text { kalibrasi } \\
\text { Grid }\end{array}$ \\
\hline ICP1 & 1.334 & 1.472 & 1.418 & 1.416 \\
ICP2 & 2.074 & 2.212 & 1.869 & 2.138 \\
ICP3 & 1.289 & 1.427 & 1.174 & 1.339 \\
ICP4 & 0.345 & 0.483 & 0.372 & 0.414 \\
ICP5 & 2.501 & 2.639 & 2.51 & 2.52 \\
\hline \hline
\end{tabular}

Hipotesa nol ditolak ditantadi berwana merah pada tabel 4, 5 dan 6. Secara umum, Koordinat hasil 3D Model Objek kalibrasi Analitik dilihat dari prosentase diterimanya hipotesa nol pada koordinat $\mathrm{X}, \mathrm{Y}$ dan $\mathrm{Z}$ berturut-turut adalah $80 \%$, $60 \%$, dan $80 \%$, sedangkan koordinat 3D Model kalibrasi Otomatis diterimanya hipotesa nol berturut-turut adalah $80 \%$, $80 \%$, dan $80 \%$. Kalibrasi Kontainer dikategorikan baik untuk sumbu X dan Z, dan cukup untuk sumbu Z. Sedangkan kualitas koordinat 3D Model Objek kalibrasi otomatis dikategorikan baik untuk sumbu X, Y dan Z. Sehingga kualitas koordinat 3D Model Objek Kalibrasi Kontainer dikategorikan baik untuk sumbu X dan Z, dan cukup untuk sumbu Z. Sedangkan kualitas koordinat 3D Model Objek kalibrasi otomatis dikategorikan baik untuk sumbu X, Y dan Z. Dari penjelasan tersebut dapat disimpulkan bahwa koordinat 3D Model kalibrasi otomatis lebih akura dari koordinat 3D Model kalibrasi analitik. Kesalahan koordinat tersebut disebabkan bentuk 3D model objek yang tidak sempurna.

\section{KESIMPULAN/RINGKASAN}

Kesimpulan yang dapat diambil dari penelitian tugas akhir ini adalah 3D Objek dapat dibentuk dengan metode CRP dapat divisualisasikan dalam bentuk point cloud dan data DEM. Selisih kalibrasi otomatis dengan analitik tidak teralu signifikan, dan nilai setiap parameter internel kamere memiliki nilai lebih besar dari hasil kalibrasi otomatis.

Hasil koordinat 3D model kalibrasi otomatis lebih akurat terhadap koordinat ICP pita ukur, yaitu $80 \%$ kordinat $\mathrm{X}, \mathrm{Y}$, dan $\mathrm{Z}$ dapat diterima, sedangkan hasil koordinat 3D model kalibrasi analitik yaitu $60 \%$ titik koordinat Y dapat diterima dan $80 \%$ titik koordinat $\mathrm{X}$ dan $\mathrm{Z}$ dapat diterima.

\section{DAFTAR PUSTAKA}

[1] Wolf, P. R., \& Dewitt, B. A. 2000. Elements of Photogrammetry with Applications in GIS: 3rd Edition. New York: McGraw Hill.

[2] Handayani, H.H., Yuwono, Taufik.M., 2015, Preliminary Study of Bridge Deformation Monitoring Using GPS and CRP (Case Study: Suramadu Bridge), Procedia Environmental Sciences Vol.24 pp.266276, Elsevier.

[3] Mulia, D., Handayani H.H., 2014, Studi Fotogrametri Jarak Dekat dalam Pemodelan 3D dan Analisis Volume Objek, Jurnal Geoid Vol.10 No.1 hal.32-39.

[4] Atkinson, K. B. 1996. Close Range Photogrammetry and Machine Vision. Scotland : Whittles Publishing.

[5] Schenk, T. 1999. Digital Photogrammetry Volime 1. TerraScience. The Ohio State University. 